\title{
Functionality Analysis of Rhus javanica Fermented by Lactobacillus spp.
}

\author{
Dong-Sung Lee', Min-Su Kang', Youn-Chul Kim,3, Nam-Kyung Im $^{4}$, Hyun-Su Kim² ${ }^{2}$ and Gil-Saeng Jeong ${ }^{4,5}$ * \\ ${ }^{1}$ Hanbang Body-Fluid Research Center, Wonkwang University, Iksan 570-749, Korea, \\ ${ }^{2}$ Department of Microbiology, College of Natural Sciences, Keimyung University, Dae-gu 704701, Korea \\ ${ }^{3}$ Standardized Material Bank for New Botanical Drugs, College of Pharmacy, Wonkwang University, Iksan 570-749, Korea \\ ${ }^{4}$ Institute for New Drug Development, Keimyung University, Dae-gu 704701, Korea \\ ${ }^{5}$ College of Pharmacy, Keimyung University, Daegu 704-701, Korea
}

Received November 2, 2012 /Revised November 5, 2012 /Accepted November 26, 2012

\begin{abstract}
To determine the potential function of Rhus javanica in Korean medicine, it was fermented with each strain of Lactobacillus spp. Each strain of Lactobacillus spp. was inoculated in lactobacilli MRS broth, and $5 \mathrm{mg} / \mathrm{ml}$ of methanol extract of Rhus javanica was added. In mouse hippocampal HT22 cells, ethyl acetate extract of $R$. javanica fermented with $L$. brevis KCTC 3498 induced heme oxygenase- 1 expression and showed a significant cytoprotective effect on glutamate-induced oxidative damage. The cytoprotective effect was related to the transcription of the nuclear factor E2-related factor2 (Nrf2), which is responsible for the induction of heme oxygenase- 1 within the nucleus. The antimicrobial, antioxidant, and heme oxygenase- 1 expression activities of fermented $R$. javanica were measured after extraction with ethyl acetate. $R$. javanica fermented with $L$. plantarum subsp. plantarum KCTC 3108, $L$. fermentum KCTC 3112, and L. brevis KCTC 3498 had higher antioxidant activity than nonfermented $R$. javanica. The fermented $R$. javanica with $L$. plantarum subsp. plantarum KCTC 3108, L. casei KCTC 3109 after ethyl acetate extraction showed antibacterial activity against Bacillus subtilis PCI 219, Escherichia coli KCTC 1682, Shigella flexneri KCTC 2517, Vibrio parahaemolyticus KCTC 7471, and Pseudomonas aeruginosa KCTC 2004. An ethyl acetate extract of the fermented $R$. javanica with Lactobacillus brevis KCTC 3498 exhibited stronger antibacterial activity than a nonfermented one against strains of $B$. subtilis PCI 219, E. coli KCTC 1682, S. flexneri KCTC 2517, and V. parahaemolyticus KCTC 7471.
\end{abstract}

Key words : Lactobacillus, Rhus javanica, neuroprotective effects, antimicrobial effects, antioxidant effects

\section{서 론}

한약재는 주로 한·중·일 3국을 중심으로 체계적인 의료기관 에 의해 사용되고 있지만 전 세계 인구의 $80 \%$ 가 전통한약에 직·간접적으로 의존하고 있으며 중국에서는 지난 10 년간 평균 $18 \%$ 씩 한약재 시장규모가 증가되는 등 전통한약에 대한 수요 가 폭발적으로 증가되고 있다[9]. 한약재를 자연에서 채취한 그대로 이용하는 것은 사용하기 불편하거나 부작용 등이 있어 독성 및 약성의 완화, 효능의 변화 등을 목적으로 한 수치라는 간단한 공정을 거쳐 사용하여 왔다. 수치는 천연상태로부터

\footnotetext{
*Corresponding author: Hyun-Su Kim

Tel : +82-53-580-5284, Fax : +82-53-580-6645

E-mail : hskim@kmu.ac.kr

*Corresponding author: Gil-Saeng Jeong

Tel : +82-53-580-6649, Fax : +82-53-580-6645

E-mail : gsjeong@kmu.ac.kr

This is an Open-Access article distributed under the terms of the Creative Commons Attribution Non-Commercial License (http://creativecommons.org/licenses/by-nc/3.0) which permits unrestricted non-commercial use, distribution, and reproduction in any medium, provided the original work is properly cited.
}

가공 처리하여 물리·화학적 및 생물학적 활성 변화를 유도하 는 한방의 전통적인 제약기술로서 오늘날까지 전래되어 이용 되고 있다[8]. 발효한약은 전통발효공법을 통해 한약재를 미생 물이 잘 이용할 수 있게 찌거나 삶은 다음 공기 중의 미생물 또는 유산균과 같은 순수분리미생물을 이용하여 발효한 한약 을 말한다. 이는 한약성분의 체내흡수율과 생체 이용률을 극 대화시킨 일종의 가공방법으로 약리적 기능성뿐만 아니라 한 약의 제형을 개선시킬 수 있다[6].

이러한 발효한약의 장점을 개략적으로 요약해 보면 다음과 같다. 첫째, 일반 한약에 비하여 맛이 좋다. 한약에서 체내 흡 수율이 떨어지고 많은 부분을 차지하는 전분을 효소가 분해하 여 당을 생산하게 하므로 쓴맛이 감소하고 풍미가 개선된다. 둘째, 약효가 빠르고 뛰어나며 소화도 용이하고 유효성분의 흡수율이 훨씬 높다. 탕전하는 방법으로는 유효성분을 40 $50 \%$ 정도밖에 추출할 수 없지만 한약재를 발효하면 저 분자화 되면서 세포 간의 결합을 끊어 세포 속의 유효성분까지 추출 되므로 $90 \%$ 이상 추출할 수 있으며 입자가 더 적은 상태이므로 흡수율을 높일 수 있다. 또한 미세한 분자구조로 추출되어 장 내흡수 후 생체 이용률이 높다. 압력식 고온 추출기의 한계성 을 극복하여 한약재의 지표물질과 유효성분의 추출 문제에 
도움이 되는 미생물을 이용한 발효 나노 추출 방법은 기타 방법으로 추출된 약재보다 빠른 체내흡수가 용이할 뿐만 아니 라 위장장애나 내장의 약화 등 소화흡수에 문제가 있는 환자 들에게도 유용하다. 셋째, 발효에 의해서 많은 효소가 생산된 다. 생산되는 효소 중에서 항산화 효소가 많이 생산되므로 피 부 개선, 노화 예방 등과 더불어 효소는 혈액과 체내노폐물을 정화하기 때문에 발효한약은 어혈과 염증 개선에 많은 효과를 나타낸다. 넷째, 저온 농축으로 효과를 증강시킨다. 진공 감압 하여 $80^{\circ} \mathrm{C}$ 이하에서 농축하므로 약효가 휘발되는 것을 줄일 수 있으며 한약이 20 배 이상 고농축 된 상태이므로 복용하기 가 훨씬 용이하다. 다섯째, 미생물 발효와 2차에 걸친 정밀여 과 과정을 통해 농약과 중금속으로부터 안전하고, 항균성과 항곤충성이 강한 한약재나 독성을 지닌 한약재도 액체나 고체 를 가리지 않고 발효가 가능하므로 독성을 제어하는데 도움이 된다. 더욱이 한약재에 함유되어 있는 잔류농약, 중금속뿐만 아니라 방부제, 표백제 등의 유해성분을 발효나 추출을 통하 여 제거할 수 있다. 이처럼 미생물 발효산물은 독성과 부작용 을 유발하는 원인물질을 해결할 수 있을 뿐만 아니라 체질에 따른 부작용이나 한약재의 알레르기 문제의 개선이 가능하다 [10]. 발효한약의 기능성에 대한 연구는 주로 항산화, 항암 및 알레르기 억제효과를 확인하여 이루어지고 있다. 선행연구들 을 살펴보면 버섯균사체로 복령과 후박을 발효하였을 때 항산 화 효과가 다소 떨어졌으나 인체 간암 세포주에서 항암 활성 이 뚜렷하게 나타났다는 보고[18]와 용안육을 청국균으로 발 효하였을 때 전자 공여능이 높고 자궁경부암세포 및 간암세포 에 대한 항암 활성이 높아졌다는 보고[19]가 있다. 또한 씀바귀 추출물을 유산균으로 발효하였을 때 씀바귀 추출물보다 알레 르기 억제 효과가 개선되었다는 보고[13]가 있으며, 발효녹용 이 녹용보다 면역증강작용이 우수하다는 보고[7]도 있다.

따라서, 본 연구에서는 한약의 발효에 의한 신기능개발을 규명하기 위한 일환으로, 선행연구[16]에서 항생제 다제 내성 균 Pseudomonas aeruginosa에 우수한 항균활성을 나타낸 10 가 지 (구기자, 금은화, 길경, 단삼, 오미자, 붉나무, 정향, 치자, 황금, 황련) 한약재 메탄올 추출물을 Lactobacillus spp. 균주 6 가지로 발효하여 총 70 개의 샘플을 이용하여 글루타메이트 로 유발한 세포 독성에 대한 뇌세포 보호 효과를 살펴 보았다. 그 가운데 가장 우수한 효과를 나타낸 붉나무 잎 추출물을 이용한 발효 에틸아세테이트 추출물의 다양한 활성 효과를
살펴보고자, HO-1의 발현 유도를 통한 뇌세포 보호 효과와 활성산소종 소거능, 항산화 효과 및 Pseudomonas aeruginosa이 외 다른 세균이나 식물병원균에 대해 항균활성을 검색하고자 하였다.

\section{재료 및 방법}

\section{한약재의 선정과 유용미생물의 선정 및 배양}

발효에 사용한 한약재는 선행연구를 통하여 다제내성 Pseudomonas aeruginosa에 항균효과가 있는 한약재를 선정하 였으며[16], 구기자, 금은화, 길경, 단삼, 오미자, 붉나무, 정향, 치자, 황금, 황련등 10 가지 약재는 대구광역시 약전골목 내 한약방에서 구입하여 사용하였다. 유용미생물은 GRAS 미생 물로서 유산균[5]을 선정하였으며, Table 1에서 보는 바와 같 이 한국생명공학연구원 유전자원센터 유전자은행(KCTC)에 서 분양을 받아 lactobacilli MRS배지(proteose peptone NO. 3. $10 \mathrm{~g} / \mathrm{l}$, beef extract $10 \mathrm{~g} / \mathrm{l}$, yeast extract $5 \mathrm{~g} / \mathrm{l}$, dextrose $20 \mathrm{~g} / \mathrm{l}$, polyoxyethylene sorbitan monooleate $1 \mathrm{~g} / \mathrm{l}$, ammonium citrate $2 \mathrm{~g} / \mathrm{l}$, magnesium sulfate $0.1 \mathrm{~g} / \mathrm{l}$, manganese sulfate $0.05 \mathrm{~g} / \mathrm{l}$, dipotassium phosphate $2 \mathrm{~g} / \mathrm{l}$, sodium acetate $5 \mathrm{~g} / \mathrm{l}, \mathrm{pH}$ 6.5, Difco Co.)에 계대배양한 후 균체를 $20 \%$ glycerol이 포함된 저장액에 넣어 $-70^{\circ} \mathrm{C}$ 에 보관하였으며, 실험 에 사용하기 전 계대배양을 실시하였다.

\section{한약재 발효를 통한 Ethyl acetate 추출물 제조 및 $\mathrm{TLC}$ pattern 분석}

한약재의 발효는 사용 한약재의 methanol 추출 농축액을 $5 \mathrm{mg} / \mathrm{ml}$ 의 농도로 MRS배지에 첨가하여 멸균하였다. 유산균 배양시 사용한 균주는 Table 1에 나타내었으며, 접종양은 $1 \times 10^{8} \mathrm{CFU} / \mathrm{ml}$ 로 stock액을 제조한 후 유산균을 $0.2 \%(\mathrm{v} / \mathrm{v})$ 가 되도록 농축액을 첨가하여 멸균된 MRS 배지에 접종하였다. 배양 시 조건은 $37^{\circ} \mathrm{C}$ 에서 7 일간 배양하였다. 배양액은 $4^{\circ} \mathrm{C}$, $1,000 \times \mathrm{g}$ 에서 10 분간 원심분리 후 상등액을 분리하였다. 발효 한약재의 추출은 발효 후 얻은 상등액 $50 \mathrm{ml}$ 에 ethyl acetate $100 \mathrm{ml}$ 를 첨가하여 수행하였으며, 2희 반복하여 실시하였다. 발효 전 methanol 추출물도 역시 같은 방법으로 ethyl acetate $100 \mathrm{ml}$ 를 첨가하여 2회 반복하였다. 발효 전 methanol 추출의 ethyl acetate 분획물과 발효 한약재의 ethyl acetate 추출물은

Table 1. Used Lactobacillus spp. strains

\begin{tabular}{ll}
\hline Strains & Sources \\
\hline Lactobacillus plantarum subsp. plantarum KCTC 3108 & Pickled cabbage \\
Lactobacillus casei KCTC 3109 & Cheese \\
Lactobacillus fermentum KCTC 3112 & Fermented beets \\
Lactobacillus brevis KCTC 3498 & Human feces \\
Lactobacillus helveticus KCTC 3545 & Emmental (Swiss) cheese \\
Lactobacillus delbrueckii subsp. bulgaricus KCTC 3635 & Bulgarian yogurt \\
\hline
\end{tabular}


소량의 $\mathrm{Na}_{2} \mathrm{SO}_{4}$ 을 첨가하여 수분을 제거하고 filter paper로 여 과한 후 rotary vacuum evaporator (EYELA, Tokyo Rikakikai Co. A-3-S. Japan)를 이용하여 감압 농축하였다. 발효에 의한 한약재의 성분변화를 관찰하기 위해 TLC pattern 분석을 수행 하였다. 6 균주로 발효한 붉나무의 ethyl acetate 추출물 중에서 HO-1 발현에 활성을 보인 KCTC 3498으로 발효한 붉나무 eth$\mathrm{yl}$ acetate 추출물과 메탄올 추출물과의 TLC를 통한 발효 전과 후의 생성물의 pattern을 확인하였다. 붉나무의 methanol 추 출의 ethyl acetate 분획물 $(10 \mathrm{mg} / \mathrm{ml})$ 과 각각 발효한 ethyl acetate 추출물 $(10 \mathrm{mg} / \mathrm{ml})$ 은 TLC plate (Silica gel 60 F254, Merck Co.)에 각각 $10 \mu 1$ 를 점적하고 건조시킨 후 전개용매 (Hexane:Acetone=1:1)가 들어 있는 TLC chamber에서 전개시 켰다. 전개시킨 TLC plate는 U.V. lamp $254 \mathrm{~nm}, 365 \mathrm{~nm}$ 과 $10 \%$ 황산에 발색하여 확인하였다. 그 결과 발효 전에 비해 발효한 붉나무 ethyl acetate 추출물에서 $\mathrm{R}_{\mathrm{f}}=0.35,0.45,0.72$ 등에서 발효 전보다 강한 spot으로 나타남을 확인하였다.

\section{세포배양 및 뇌 세포 보호활성 측정 방법}

마우스 해마 유래 HT22 세포주는 묵인희 교수(서울대학교) 로부터 분양받아 사용하였다. HT22 세포는 $10 \%$ heat-inactivated $\mathrm{FBS}$, penicillin $\mathrm{G}(100 \mathrm{IU} / \mathrm{ml})$ 와 streptomycin (100 $\mu \mathrm{g} / \mathrm{ml}$ )을 함유한 $\mathrm{DMEM}$ 배지에 분주하여 $37^{\circ} \mathrm{C}, 5 \% \mathrm{CO}_{2}$ 배양 기 내에서 24시간 배양하였다. HT22 세포주는 96 well plate에 well당 $1 \times 10^{5}$ cells 밀도로 분주하여 24 시간 배양 후 각각의 시료 용액과 $5 \mathrm{mM}$ glutamate를 처리한 후 12 시간 동안 $37^{\circ} \mathrm{C}$, $5 \% \mathrm{CO}_{2}$ 배양기 내에서 배양하였다. 세포 생존율은 MTT법을 통해 확인하였으며, 양성대조약물은 $50 \mu \mathrm{M}$ 의 Trolox를 사용 하였다. 보호활성은 ELISA reader를 사용하여 $540 \mathrm{~nm}$ 의 측정 파장을 기준으로 하여 흡광도를 측정하여 확인하였다.

\section{활성산소종 소거능 측정 방법}

HT22 세포 $\left(2 \times 10^{4}\right.$ cells $/ \mathrm{ml}$ in 24 -well plate)를 시료용액과 $5 \mathrm{mM}$ glutamate를 처리한 후 12시간 동안 $5 \% \mathrm{CO}_{2}$ 배양기 내에 서 배양하고, PBS로 세척한 후, $10 \mu \mathrm{M} \mathrm{2} 2^{\prime}, 7^{\prime}$-dichlofluorescein diacetate (DCFDA, 35845)를 포함하는 Hank's balanced salt 용액에서 30 분 동안 암실에서 반응시켰다. 반응 후 PBS로 두 번 세척하고 $1 \%$ Triton X-100이 포함된 PBS에 $37^{\circ} \mathrm{C}$ 에서 10 분 간 방치 후 세포의 형광도(Spectramax Gemini XS, Molecular Devices, Sunnyvale, CA, USA)를 측정하였다(excitation wave length: $490 \mathrm{~nm}$; emission wave length: $525 \mathrm{~nm}$ ).

\section{Western blot analysis 방법}

HT22 세포는 $60 \mathrm{~mm}$ dish에 $3 \times 10^{5}$ cells/well의 밀도로 24 시간 배양하였으며, 각각의 시료는 농도와 시간을 달리하여 처리하였다. 시료 처리 후 HT22 세포는 RIPA buffer를 첨가한 후 $4^{\circ} \mathrm{C}, 14,000 \times g^{\circ}$ 에서 25 분간 원심분리하여 제거하고, 상등액
은 Bradford 방법을 통해 Quick Start Bradford Protein Assay Kit (500-0201, Bio-Rad Co.)를 이용하여 단백질을 정 량하였다. 단백질을 정량한 시료는 $12 \%$ SDS-PAGE로 전기영동하고, $\mathrm{NC}$ membrane으로 전사하였다. 전사된 NC membrane은 $5 \%$ 무 지방유가 포함된 blocking buffer $(0.1 \%$ Tween 20 in Tris-buggered saline)로 blocking하여 HO-1 antibody를 $1: 1,000$ 으로 희석한 후 첨가하여 1 시간 동안 반응시켰으며, 2 차 antibody (Anti-mouse $\operatorname{IgG}$ )를 1:1,000으로 희석하여 첨가 한 후 1 시간 동안 반응시켰다. 발현 분석은 항체를 처리한 $\mathrm{NC}$ membrane위에 ECL용액을 1:1로 가하여 발광시키고 암실에 서 $X$ 선 필름에 감광한 후 현상하여 수행하였다. Actin은 동일 한 방법으로 actin antibody를 이용하여 측정하였다.

\section{핵과 세포질 분획의 분리}

HT22 세포의 균질화는 protease inhibitor cocktail I과 1 $\mathrm{mM}$ PMSF를 첨가한 PER-mammalian protein extraction buf$\mathrm{fer}$ 를 첨가하여 수행하였으며, $4^{\circ} \mathrm{C}$ 에서 $15,000 \times g$ 로 10 분간 원 심분리 하여 상등액을 회수하였다. 상등액은 세포질 분획으로 사용하기 위하여 $-80^{\circ} \mathrm{C}$ 에 보관하였으며, 나머지 침전물은 PBS 로 세척하여 RIPA buffer를 첨가하고 $4^{\circ} \mathrm{C}$ 에서 15 분간 혼합한

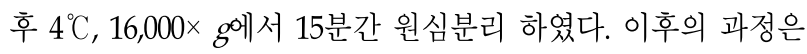
앞에서 설명한 western blotting 방법으로 수행하였다.

\section{폴리페놀함량 측정 방법}

폴리페놀 함량은 Folin-denis 방법[21]을 변경하여 96 well 에 적용하여 측정하였다. 발효 한약재와 ethyl acetate 추출물 은 증류수로 희석하여 각각 $60 \mu 1$ 를 2배 희석한 folin reagent $60 \mu \mathrm{l}$ 에 첨가시켜 3분간 반응시키고, $10 \% \mathrm{Na}_{2} \mathrm{CO}_{3}$ 를 $60 \mu 1$ 첨가 하여 30 분간 실온에서 반응시켰다. 반응 용액은 microplate reader를 사용하여 $700 \mathrm{~nm}$ 에서 흡광도를 측정하였다. 폴리페 놀 함량은 tannic acid를 지표물질로 이용하여 작성한 표준곡 선으로 산출하였다.

\section{ABTS free radical 소거능 측정 방법}

ABTS free radical을 이용한 항산화력 측정은 ABTS cation decolourisation assay 방법[14]으로 측정하였다. ABTS radical 은 $7 \mathrm{mM} \mathrm{ABTS}$ 용액과 $2.45 \mathrm{mM}$ potassium persulfate 용액을 1:1로 혼합하여 실온의 암소에서 24시간 반응시킨 후 생성시 켰으며, $732 \mathrm{~nm}$ 에서 흡광도 값이 $0.7 \pm 0.02$ 가 되도록 $\mathrm{PBS}$ 로 희석하여 사용하였다. 희석된 $20 \mu 1$ 의 시료는 ABTS free radi$\mathrm{cal}$ 용액 $180 \mu \mathrm{l}$ 에 혼합하여 1분간 반응시킨 후 $732 \mathrm{~nm}$ 에서 흡광도를 측정하였다. 각 시료 추출물의 free radical 소거활성 은 시료를 첨가하지 않은 대조구의 흡광도를 $1 / 2$ 로 환원시키 는데 필요한 시료의 농도인 $\mathrm{RC}_{50}$ 값으로 나타내었으며, 대조 군으로 Trolox를 사용하였다.

DPPH free radical 소거능 측정 방법

시료의 free radical 소거능은 안정한 radical인 DPPH에 대 
한 환원력을 측정 후 확인하였다. Methanol에 용해시켜 농도 별로 희석한 시료 $20 \mu \mathrm{l}$ 는 methanol에 용해시킨 $0.15 \mathrm{mM}$ $\mathrm{DPPH}$ 용액 $80 \mu \mathrm{l}$ 와 혼합하고 실온의 암소에서 30 분간 반응시 킨 후 $517 \mathrm{~nm}$ 에서 흡광도를 측정하였다. 각 시료 추출물의 free radical 소거활성은 시료를 첨가하지 않은 대조구의 흡광 도를 $1 / 2$ 로 환원시키는데 필요한 시료의 농도인 $\mathrm{RC}_{50}$ 값으로 나타내었으며, 대조군으로 BHA를 사용하였다.

\section{항균활성 측정 방법}

항균활성은 agar diffusion법으로 측정하였다. 시험 균주는 Table 2에서 보는 바와 같은 세균과 식물병원균을 사용하였다. 세균은 LB 배지(peptone $10 \mathrm{~g} / \mathrm{l}$, yeast extract $5 \mathrm{~g} / \mathrm{l}$, sodium chloride $5 \mathrm{~g} / \mathrm{l}, \mathrm{pH}$ 6.8), $\mathrm{MB}$ 배지(peptone $5 \mathrm{~g} / \mathrm{l}$, yeast extract $1 \mathrm{~g} / \mathrm{l}$, ferric citrate $0.1 \mathrm{~g} / \mathrm{l}$, sodium chloride $19.45 \mathrm{~g} / \mathrm{l}$, magnesuim chloride $8.8 \mathrm{~g} / \mathrm{l}$, sodium sulfate $3.24 \mathrm{~g} / \mathrm{l}$, calcium chloride $1.8 \mathrm{~g} / \mathrm{l}$, potassium chloride $0.55 \mathrm{~g} / \mathrm{l}$, sodium bicarbonate $0.16 \mathrm{~g} / \mathrm{l}$, potassium bromide $0.08 \mathrm{~g} / \mathrm{l}$, agar $15 \mathrm{~g} / \mathrm{l}$, strontium chloride $34 \mathrm{mg} / \mathrm{l}$, boric acid $22 \mathrm{mg} / \mathrm{l}$, sodium silicate $4 \mathrm{mg} / \mathrm{l}$, sodium fluoride $2.4 \mathrm{mg} / \mathrm{l}$, ammonium nitrate $1.6 \mathrm{mg} / \mathrm{l}$, disodium phosphate $8 \mathrm{mg} / \mathrm{l}, \mathrm{pH}$ 7.6)와 Nutrient 배지(beef extract $3 \mathrm{~g} / \mathrm{l}$, peptone $5 \mathrm{~g} / \mathrm{l}, \mathrm{pH}$ 6.8, Difco Co.)에 계대배양 하였으며, 식물병원균은 PDA 배지(potato starch $4 \mathrm{~g} / \mathrm{l}$, dextrose $20 \mathrm{~g} / \mathrm{l}$, agar $15 \mathrm{~g} / \mathrm{l}, \mathrm{pH}$ 5.1, Difco Co.)에 계대배양한 후 $4{ }^{\circ} \mathrm{C}$ 에 보관하면서 사용하였다. 항균활성은 시료 $20 \mu 1$ 를 paper disc ( $\varnothing=6 \mathrm{~mm}$ Whatman $\mathrm{Co}_{\text {.) }}$ )에 첨가하여 건조시킨 후 검정 균주가 함유된 평판배지 위에 얹고 세균은 1 일간 배 양, 식물병원균은 7일간 배양한 후 생성된 inhibitory zone의 유무 및 크기를 통해 판단하였다.

\section{$\mathrm{pH}$ 측정 방법}

한약재 추출액과 ethyl acetate 추출물 그리고 ethyl acetate 로 추출하고 남은 물층의 $\mathrm{pH}$ 측정은 각 시료들의 항균활성에
$\mathrm{pH}$ 가 영향을 미치는지 확인하기 위해 수행 하였다. $\mathrm{pH}$ 측정 은 $\mathrm{pH}$ meter를 이용하였다.

\section{결 과}

뇌세포 보호활성 및 활성산소종(ROS) 생성 억제 효과

산화적 스트레스에 의한 세포 손상은 파킨슨 증후군, 헌팅 턴 증후군, 알츠하이머 증후군 등과 같은 퇴행성 뇌질환의 중 요한 요인으로 알려져 있으며, 그 중에서 glutamate에 의한 산화적 스트레스로 유발되는 뇌세포 손상은 퇴행성 뇌질환의 주요한 요인으로 보고되고 있다[15]. 따라서 본 연구에서는 10 종(구기자, 금은화, 길경, 단삼, 오미자, 붉나무, 정향, 치자, 황 금, 황련) 한약재 메탄올 추출물을 Lactobacillus spp. 균주 6가 지로 발효하여 총 70 개의 샘플을 이용하여 글루타메이트로 유발한 세포 독성에 대한 뇌세포 보호 효과를 살펴 보았다. 그 결과 Lb. brevis KCTC 3498에 의해 발효된 붉나무의 ethyl acetate 추출물은 $\mathrm{HT} 22$ 세포에 50, $200 \mathrm{\mu g} / \mathrm{ml}$ 로 처리 시 75, $85 \%$ 의 세포 보호효과가 있었으며, 발효 전 메탄올 추출물에 비해 증가한 보호효과를 보였다. 또한, 황련 메탄올 추출물과 황련 $\mathrm{Lb}$ b brevis KCTC 3545 발효된 추출물의 $200 \mu \mathrm{g} / \mathrm{ml}$ 농도 에서 각각 $50 \%$ 와 $69 \%$ 의 세포 보호 효과가 있었다. 다른 8 종의 한약재는 메탄올 추출물을 비롯한 발효된 추출물 모두에서 보호 효과가 없었다(결과 생략). 양성대조약물로는 $50 \mu \mathrm{M}$ 의 Trolox를 사용하였다. 이 결과를 바탕으로 붉나무의 경우 발효 전 메탄올 추출물에 비해, 발효 후 에틸아세테이트 추출물의 보호 효과가 현저하게 증가 했으므로 붉나무를 이용한 추출물 을 가지고 다양한 활성 실험을 진행 하였다.

Lb. brevis KCTC 3498 로 발효시킨 붉나무의 ethyl acetate 추출물은 높은 뇌세포 보호활성을 나타내어 처리 농도에 따른 뇌세포 보호활성 및 활성산소종(ROS) 억제 효과를 측정 하였 다. 그 결과 Fig. $1 \mathrm{~A}$ 와 $1 \mathrm{~B}$ 에서 보는 바와 같이 Lb brevis $\mathrm{KCTC}$

Table 2. Test strains used for determination of antimicrobial activity

\begin{tabular}{clc}
\hline & \multicolumn{1}{c}{ Test strains } & Medium \\
\hline & Bacillus subtilis PCI 219 & Nutrient \\
Escherichia coli KCTC 1682 & LB \\
Bacteria & Nutrient & LB \\
& Shigella flexneri KCTC 2517 2004 & MB \\
& Vibrio parahaemolyticus KCTC 7471 & \\
& Fusarium oxysporum f. sp. lycopersici (Saccardo) Snyder \& Hansen KACC 4003 \\
& Rhizoctonia solani AG(IA) Kuhn KACC 40101 & PDA \\
& Rhizoctonia solani AG Kuhn KACC 40142 & \\
& Phytophthora capsici Leonian KACC 40476 & \\
& Marssonina rosae (Lib.) Died KACC 40490 & \\
& Colletotrichum orbiculare (Berkeley \& Montagen) von Arx KACC 40808 & \\
& Botrytis cinerea Pers. KACC 40854 & \\
& Fusarium oxysporum f. sp. niveum W.C. Snyder \& H.N. Hansen KACC 40902 \\
& Botryris cinerea Pers KACC 40965 &
\end{tabular}


3498로 발효시킨 붉나무의 ethyl acetate 추출물이 유의한 뇌 세포 보호활성 및 ROS 생성 억제 효과를 나타내었으며, 이를 바탕으로 처리 농도를 $25,50,100$ 과 $200 \mu \mathrm{g} / \mathrm{ml}$ 로 조절하여 메탄올 추출물과 비교 하였다. Fig. $1 \mathrm{C}$ 와 $1 \mathrm{D}$ 에서 보는 바와 같이 Lb. brevis KCTC 3498로 발효시킨 붉나무의 ethyl acetate 추출물은 붉나무의 메탄올 추출물보다 뇌세포 보호활성 및 $\mathrm{ROS}$ 생성억제 효과가 농도 의존적으로 증가하는 것을 확인하 였다.

\section{Heme oxygenase-1 발현 및 Nrf2 전사 효과}

Lactobacillus spp. 균주로 발효한 붉나무의 ethyl acetate 추출물에 의한 HO-1 발현은 western blot analysis를 수행 하여 확인하였다. Fig. 2A에서 보는 바와 같이 Lb. brevis KCTC 3498로 발효한 ethyl acetate 추출물이 발효 전 붉나 무 methanol 추출물과 다른 균주로 발효한 붉나무의 ethyl acetate 추출물보다 높은 HO-1의 발현을 확인하였다. HO-1 의 발현을 증가시킨 Lb. brevis KCTC 3498로 발효한 붉나무 의 ethyl acetate 추출물은 농도를 $25,50,100$ 과 $200 \mu \mathrm{g} / \mathrm{ml}$ 로 조절하여 HO-1의 발현을 확인하였다. 그 결과 발효한 붉나무의 ethyl acetate 추출물의 HO-1 발현은 Fig. $2 \mathrm{~B}$ 와 $2 \mathrm{C}$ 에서 보는 바와 같이 발효 전 붉나무의 methanol 추출물
보다 농도 의존적으로 증가하는 것을 확인하였다. $\mathrm{Nrf2}$ 는 HO-1 단백질 발현에 관여하는 메커니즘 중 핵 내로의 전사 에서 매우 중요한 인자로 작용한다고 알려져 있다. 전사인 자로서의 Nrf2는 $\mathrm{HO}-1$ 과 같은 항산화 단백질 유전자에 존 재하는 antioxidant response element (ARE)에 결합하여 이 들 유전자의 발현과 단백질 생성을 항진시킴으로써 산화적 스트레스에 대한 생체방어기전의 핵심적 역할을 담당한다 [2]. Lb. brevis KCTC 3498로 발효한 붉나무의 ethyl acetate 추출물에 의한 $\mathrm{Nrf2}$ 의 핵 내 전사 여부는 추출물을 $200 \mu$ $\mathrm{g} / \mathrm{ml}$ 농도로 하여 시간별로 처리한 후 western blot을 이용 하여 확인하였다. 시간이 경과함에 따라 세포질의 Nrf2는 점점 감소하는 반면, 핵 내부의 Nrf2는 증가하는 양상을 보 였다(Fig. 3). 이러한 결과를 통해 Lb. brevis KCTC 3498로 발효한 붉나무의 ethyl acetate 추출물이 HT22 세포에서 $\mathrm{Nrf} 2$ 를 핵 내로 전사시켜 HO-1을 발현시킴으로써 glutamate로 유도된 산화적 독성으로부터 세포를 보호하는 것으 로 사료된다.

Heme oxygenase-1 발현에 따른 뇌세포보호 효과 및 $\mathrm{ROS}$ 생성 억제 효과 측정

Lb. brevis KCTC 3498로 발효시킨 붉나무의 ethyl acetate
A

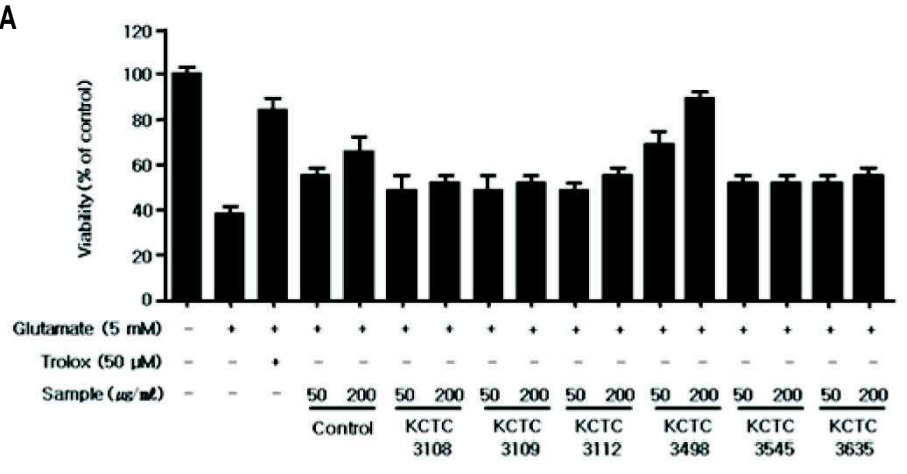

B

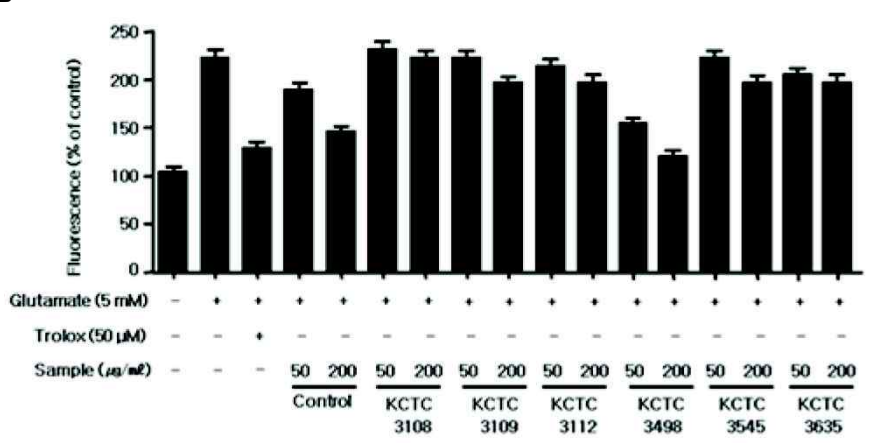

C

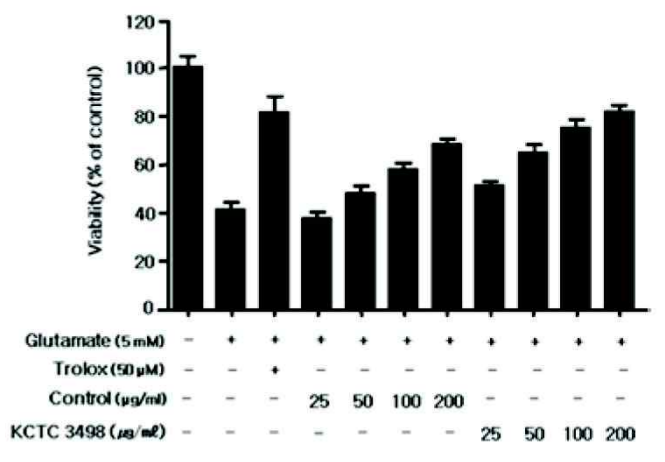

D

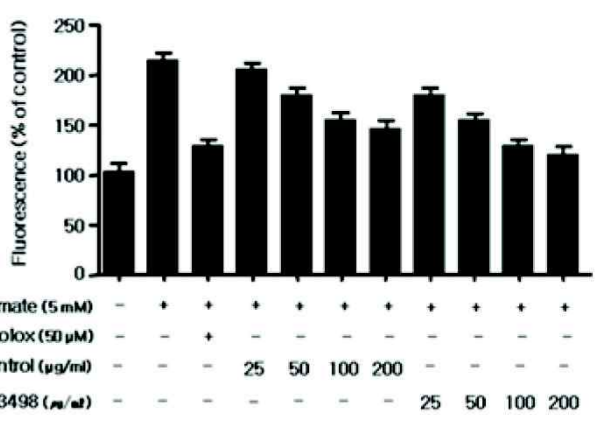

Fig. 1. Effects of 6 ethyl acetate extracts from various KCTC fermented Rhus javanica on glutamate-induced oxidative neurotoxicity (A) and ROS generation (B), and effects of Rhus javanica fermented with KCTC 3498 on glutamate-induced oxidative neurotoxicity (C) and ROS generation (D) in HT22 cells. Cells were treated with indicated concentrations of extracts, and then incubated for $12 \mathrm{hr}$ with $5 \mathrm{mM}$ glutamate. Each bar represents the mean \pm S.D. of three independent experiments. Trolox was used as the positive control. (Control=Methanol extract of Rhus javanica) 


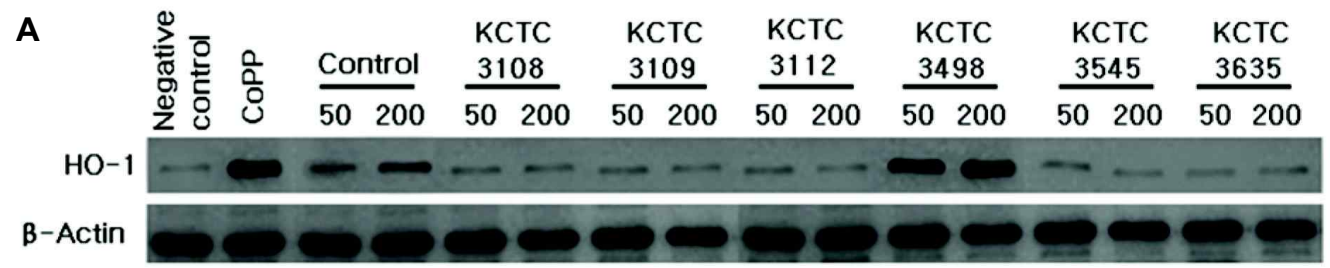

B

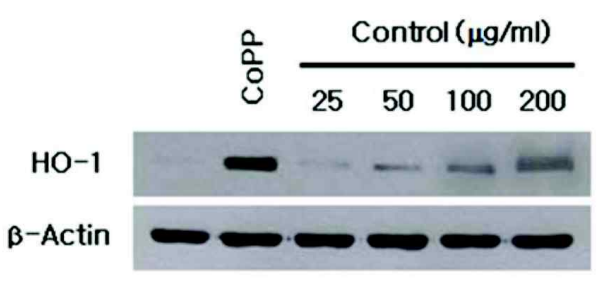

C

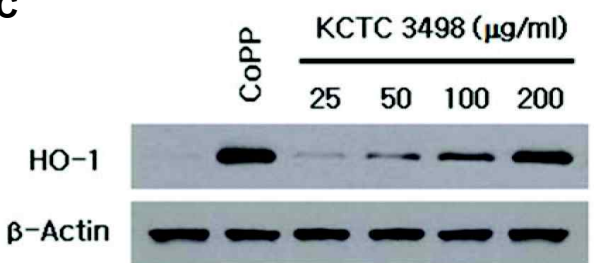

Fig. 2. Effects of 6 ethyl acetate extracts from fermented Rhus javanica (A) and effects of control (B) and KCTC 3498 (C) on HO-1 expression in HT22 cells. Cells were incubated for $12 \mathrm{hr}$ with indicated concentrations of extracts and CoPP $(20 \mu \mathrm{M})$. Expression of HO-1 was determined by western blot analysis, and representative blots of three independent experiments were shown. CoPP was used as the positive control. (Control=Methanol extract of Rhus javanica)

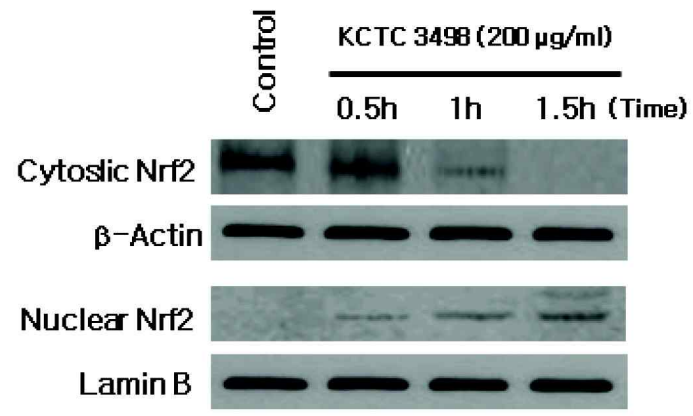

Fig. 3. Effects of KCTC 3498 (ethyl acetate extract from KCTC 3498 fermented Rhus javanica) on Nrf2 nuclear translocation in HT22 cells. Cells were incubated with $200 \mathrm{\mu g} /$ $\mathrm{ml}$ of extract for $0.5,1$ and $1.5 \mathrm{hr}$. Nrf2 protein was detected by western blot analysis, and representative blots of three independent experiments were shown.

추출물의 뇌세포 보호 효과가 HO-1의 발현유도와 직접적인 관련이 있는지를 확인하기 위해 HO-1 발현 억제제인 SnPP를 처리한 후 세포 생존율 및 ROS 생성 억제 효과를 확인하였다. Fig. 4 에서 보는 바와 같이 $\mathrm{SnPP}$ 를 처리하지 않은 시험군은 Lb. brevis KCTC 3498 로 발효한 붉나무 ethyl acetate 추출물의 농도 증가에 비례하여 세포 생존율 및 ROS 생성 억제 효과가 증가하였으며, $\mathrm{SnPP}$ 를 처리한 군은 $\mathrm{Lb}$. brevis $\mathrm{KCTC} 3498$ 로 발효한 붉나무의 ethyl acetate 추출물을 단독으로 처리하였을 때보다 감소하였다. 이러한 결과는 Lb. brevis KCTC 3498로 발효한 붉나무의 ethyl acetate 추출물이 glutamate로 유도된 산화적 스트레스로부터 세포를 보호하는데 있어 HO-1 단백질 의 발현과 관련이 있음을 나타낸다.

\section{폴리페놀 함량 측정}

페놀성 화합물은 식물계에 널리 분포되어 있는 성분의 하나
로서 다양한 구조와 분자량을 가진다. 이들은 다수의 hydrox$\mathrm{yl}(\mathrm{OH})$ 기를 가지기 때문에 단백질 및 기타 거대 분자들과 쉽게 결합하며, 항산화, 항암 등의 다양한 생리활성을 가진다 [20]. 발효한 붉나무의 폴리페놀 함량은 발효 전·후의 발효액 과 ethyl acetate 추출물을 대상으로 하여 측정하였으며, 기준 물질은 tannic acid를 사용하였다. 붉나무를 각각의 균주로 발 효한 발효액의 폴리페놀 함량은 Fig. 5 의 A에서 보는 바와 같 이 발효 전과 큰 차이가 없었다. 그러나 Ethyl acetate 추출물의 폴리페놀 함량은 Fig. 5 의 B에서 보는 바와 같이 $L b$. plantarum subsp. plantarum KCTC 3108, Lb. casei KCTC 3109, Lb. helveticus KCTC 3545와 Lb. delbrueckii subsp. bulgaricus KCTC 3635 로 발효하였을 때 발효 전보다 낮았다. Lb. fermentum KCTC 3112와 Lb. brevis KCTC 3498로 각각 발효 후 ethyl acetate 추출물의 폴리페놀 함량은 각각 $2,841 \mu \mathrm{gg} / \mathrm{ml}$ 와 $2,824 \mu \mathrm{g} / \mathrm{ml}$ 로 확인되어, 발효 전 붉나무 메탄올 추출물의 폴리페놀 함량 $(2,649 \mu \mathrm{g} / \mathrm{ml})$ 보다 높았다.

\section{ABTS free radical 소거능}

붉나무 발효액의 ABTS free radical 소거능은 Fig. 6의 A 에서 보는 바와 같이 발효 전 붉나무 methanol 추출물의 ABTS free radical 소거능과 거의 유사하였다. Lb. plantarum subsp. plantarum KCTC 3108로 발효한 붉나무의 ethyl acetate 추출물은 Fig. 6 의 B에서 보는 바와 같이 $\mathrm{RC}_{50}$ 이 $4.7 \mu \mathrm{g} /$ $\mathrm{ml}$ 로 확인되어 다른 ethyl acetate 추출물보다 ABTS free radical 소거능이 낮았으나 $L b$. fermentum KCTC 3112와 Lb. brevis KCTC 3498로 각각 발효 시 ABTS free radical 소거능 은 발효 전 붉나무 methanol 추출물의 ABTS free radical 소 거능과 유사하였다. 
DPPH free radical 소거능

붉나무의 발효액 및 ethyl acetate 추출물의 항산화 효과는 $\mathrm{DPPH}$ free radical 소거능을 측정하여 확인하였다. Fig. 7의
$\mathrm{A}$ 에서 보는 바와 같이 붉나무의 발효액 과 발효 전 붉나무의 methanol 추출물 간의 큰 차이는 보이지 않았다. 반면에 $L b$. plantarum subsp. plantarum KCTC 3108로 발효한 발효액의

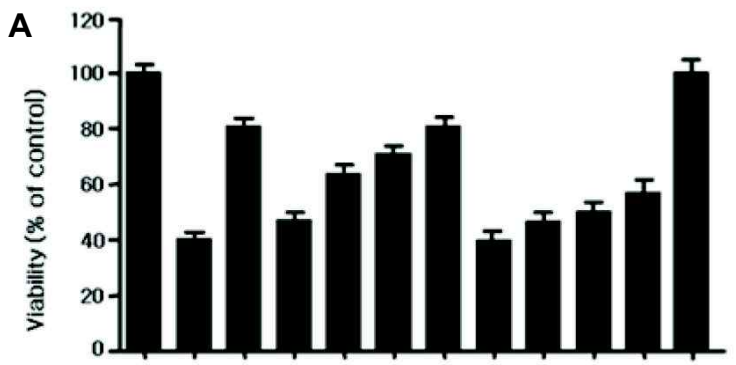

B

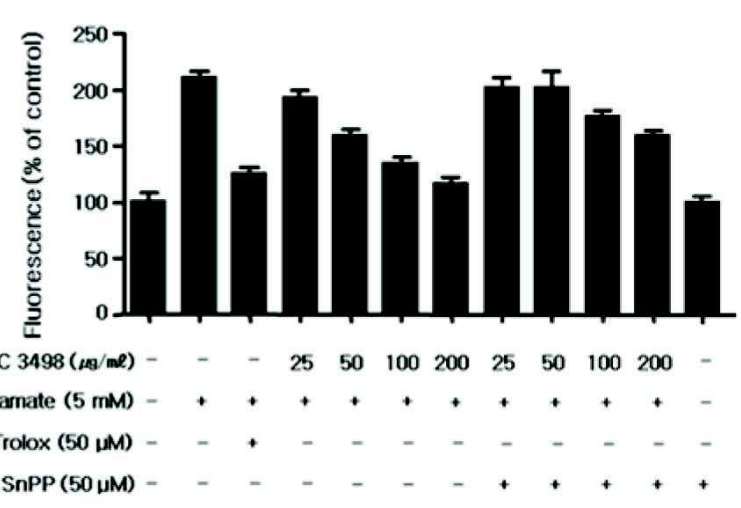

Fig. 4. Effects of HO-1 induction by KCTC 3498 (ethyl acetate extract from KCTC 3498 fermented Rhus javanica) on glutamate-induced oxidative neurotoxicity and ROS generation in HT22 cells. Cells were treated with various concentration of KCTC 3498 (25, 50,100 and $200 \mu \mathrm{g} / \mathrm{ml}$ ) and $50 \mu \mathrm{M}$ Copp in the presence or absence of $50 \mu \mathrm{M} \mathrm{SnPP}$, an inhibitor of HO activity, and then exposed to $5 \mathrm{mM}$ glutamate for $12 \mathrm{hr}$. Each bar represents the mean \pm S.D. of three independent experiments.
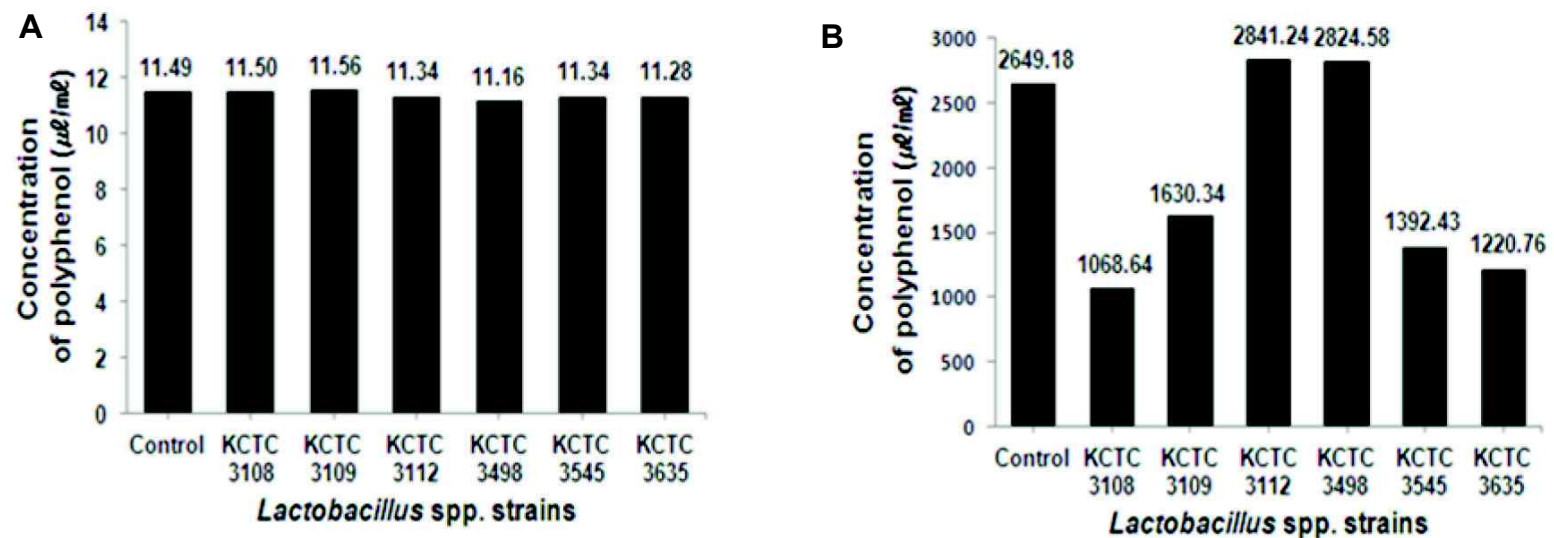

Fig. 5. Polyphenol concentration from fermented Rhus javanica. A: Fermented broth. B: Ethyl acetate extract.
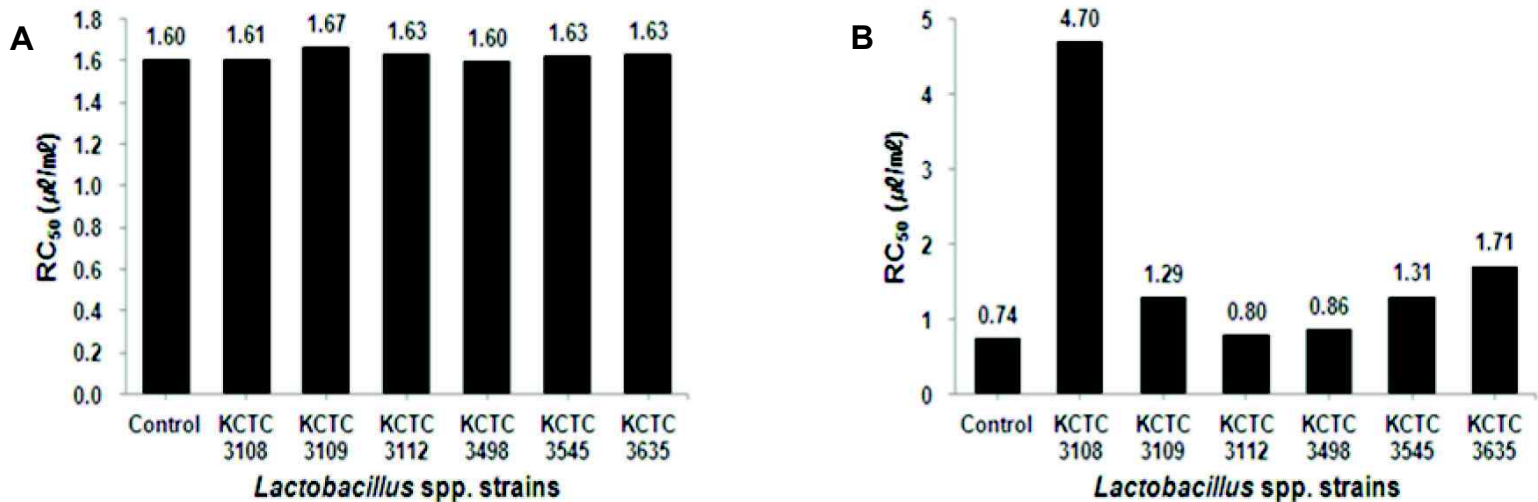

Fig. 6. ABTS free radical scavenging activity of fermented Rhus javanica. $\mathrm{RC}_{50}$ concentration required for $50 \%$ reduction of ABTS $(0.7 \mathrm{mM})$ radicals. A: Fermented broth. B: Ethyl acetate extract. 
A

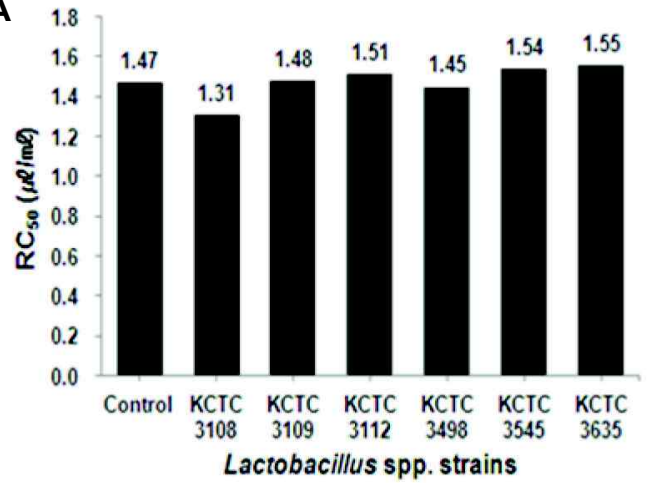

B

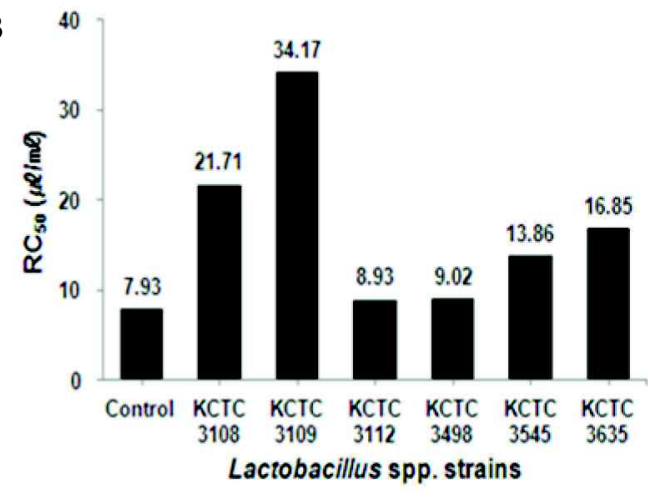

Fig. 7. DPPH free radical scavenging activity of fermented Rhus javanica. $\mathrm{RC}_{50}$ concentration required for $50 \%$ reduction of $\mathrm{DPPH}$ $(0.3 \mathrm{mM})$ radicals. A: Fermented broth. B: Ethyl acetate extract.

ethyl acetate 추출물은 Fig. 7의 B에서 보는 바와 같이 발효 전보다 $\mathrm{RC}_{50}$ 이 높아졌다. $\mathrm{Lb}$. fermentum $\mathrm{KCTC} 3112$ 와 Lb. brevis KCTC 3498로 발효한 발효액의 ethyl acetate 추출물은 발 효 전과 유사한 $\mathrm{RC}_{50}$ 을 보였다. 이는 ethyl acetate로 추출하는 과정에서 $\mathrm{DPPH}$ free radical 소거에 관여하는 물질이 많이 추출된 것으로 사료된다.

\section{항균활성}

항균활성은 붉나무의 발효액, ethyl acetate 추출물과 물층 을 대상으로 측정하였다. 물층의 항균활성 측정은 ethyl acetate로 추출한 후 항균성 물질의 잔존 유무를 알아보기 위해 수행하였다. 붉나무의 발효액과 물층은 농축을 하지 않고 항 균활성을 측정하였으며, ethyl acetate 추출물은 $1 \mathrm{mg} / \mathrm{ml}$ 의 농도로 농축하여 사용하였다. 붉나무를 $L b$. plantarum subsp. plantarum KCTC 3108과 Lb. case $\mathrm{KCTC}$ 3109로 발효시킨 발효 액은 Table 3A에서 보는 바와 같이 Bacillus subtilis PCI 219, Escherichia coli KCTC 1682, Shigella flexneri KCTC 2517, Vibrio parahaemolyticus KCTC 7471과 Pseudomonas aeruginosa KCTC 2004에 모두 항균활성을 나타내었다. 특히 붉나무를 Lb. plantarum subsp. plantarum KCTC 3108로 발효시킨 발효액은 B. subtilis PCI 219에 $18 \mathrm{~mm}$, E. coli KCTC 1682에 $7 \mathrm{~mm}$, S. flexneri KCTC 2517에 $14 \mathrm{~mm}$, V. parahaemolyticus KCTC 7471에 $11 \mathrm{~mm}$ 그리고 P. aeruginosa KCTC 2004에 $12 \mathrm{~mm}$ 의 inhibitory zone을 생성하였다. 붉나무의 ethyl acetate 추출물은 Lb. brevis KCTC 3498로 발효하였을 때 B. subtilis PCI 219에 $9.5 \mathrm{~mm}$, E. coli KCTC 1682에 $16 \mathrm{~mm}$, S. flexneri KCTC 2517에 $20 \mathrm{~mm}$ 그리고 $V$. parahaemolyticus KCTC 7471에 $13 \mathrm{~mm}$ 의 inhibitory zone을 형성하며 항균활성을 나타내었다. Ethyl acetate로 추출한 나머지인 물층은 $\mathrm{Lb}$. plantarum subsp. plantarum KCTC 3108과 Lb. casei KCTC 3109로 발효하였을 때 B. subtilis PCI 219, S. flexneri KCTC 2517, V. parahaemolyticus KCTC 7471과 P. aeruginosa KCTC 2004에 약한 항균활성을
나타내었다. Table 3B에서 보는 바와 같이 식물병원균에 대한 항균활성은 붉나무의 ethyl acetate 추출물에서만 나타났으며 그 중에서 Lb. brevis KCTC 3498, Lb. helveticus KCTC 3545와 Lb. delbrueckii subsp. bulgaricus KCTC 3635로 발효한 ethyl acetate 추출물이 Fusarium oxysporum f. sp. Lycopersici (Saccardo) Snyder \& Hansen KACC 40037에 항균활성을 나 타냈다.

\section{$\mathrm{pH}$ 측정}

붉나무의 발효액, ethyl acetate 추출물과 남은 여액층의 $\mathrm{pH}$ 는 항균활성에 영향을 미치는지 확인하기 위해 측정하였다. Table 3 C에서 보는 바와 같이 배양 7 일째의 발효액 $\mathrm{pH}$ 는 $L b$. plantarum subsp. plantarum KCTC 3108, Lb. casei KCTC 3109 로 발효하였을 때 3.8 로 측정되었으며, ethyl acetate로 추출 시 $\mathrm{pH}$ 가 더 낮아졌다. Ethyl acetate 추출물은 발효액보다 $\mathrm{pH}$ 가 낮게 측정되었지만, E. coli KCTC 1682와 S. flexneri KCTC 2517에만 항균활성을 보였다. 또한 Lb. plantarum subsp. plantarum KCTC 3108, Lb. casei KCTC 3109, Lb. helveticus KCTC 3545와 Lb. delbrueckii subsp. bulgaricus KCTC 3635로 발효 후 ethyl acetate 추출물의 $\mathrm{pH}$ 가 3이지만 항균활성을 보이지 않았 다. 이러한 결과를 통해 발효액, ethyl acetate 추출물과 남은 여액층의 낮은 $\mathrm{pH}$ 는 항균활성에 크게 영향을 주지 않은 것으 로 확인되었다.

\section{고 찰}

최근 발효한약을 이용하는 방법이 다양하게 연구 되고 있 다. 발효한약은 전통발효공법을 통해 한약재를 미생물이 잘 이용할 수 있게 찌거나 삶은 다음 공기 중의 미생물 또는 유산 균과 같은 순수분리미생물을 이용하여 발효한 것으로, 이는 한약성분의 체내흡수율과 생체 이용률을 극대화시킨 일종의 가공방법으로 약리적 기능성뿐만 아니라 한약의 제형을 개선 
Table 3. Antibacterial activity of culture broth, ethyl acetate extract and aqueous layer from fermented Rhus javanica (A), antifungal activity of ethyl acetate extract from fermented Rhus javanica (B), and $\mathrm{pH}$ pattern of fermented Rhus javanica by Lactobacillus strains (C)

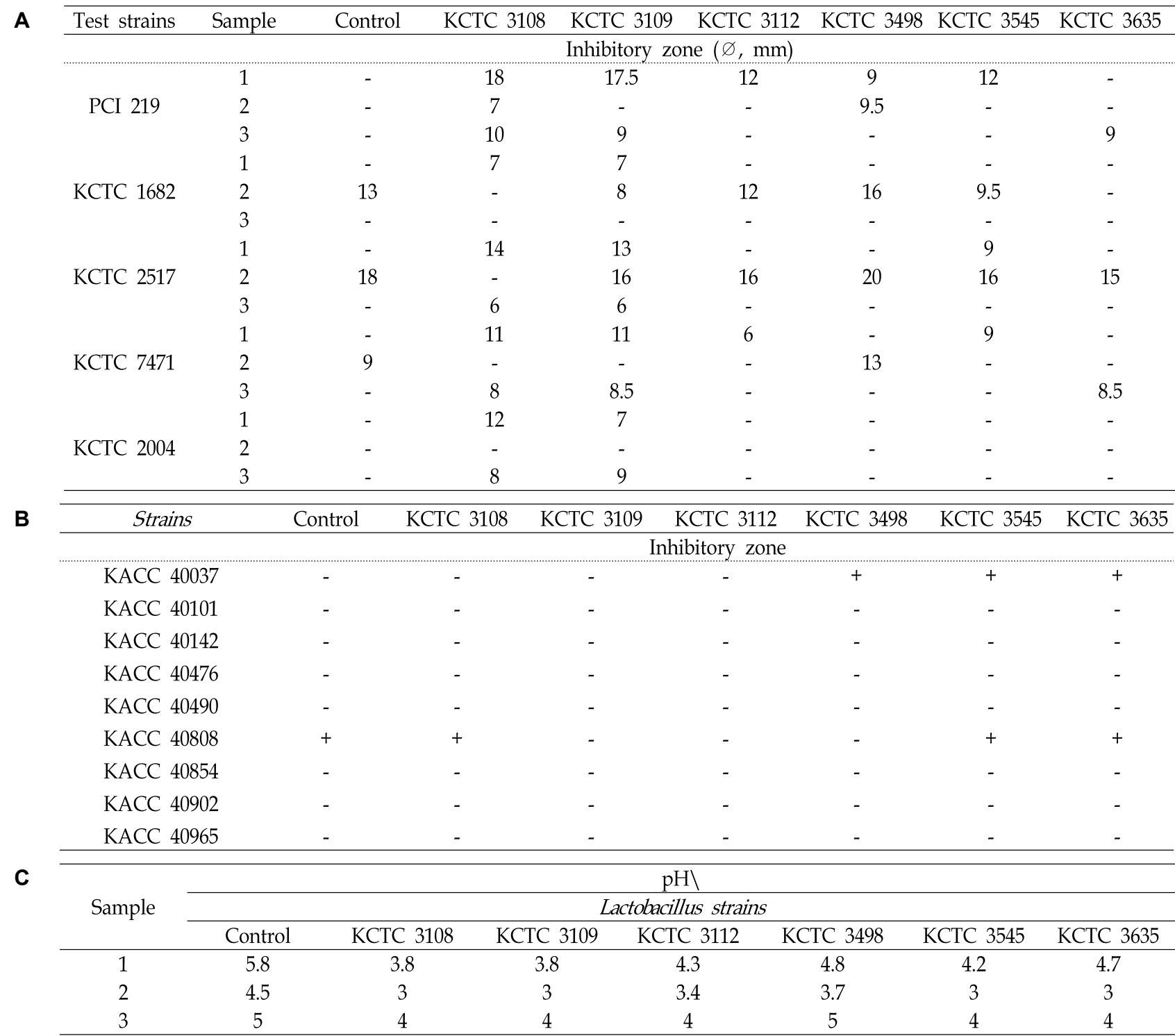

-: Un-inhibition. +: Inhibition.

1: Culture broth of fermented Rhus javanica, 2: Ethyl acetate extracts, 3: Aqueous layer after ethyl acetate extraction.

시킬 수 있다고 잘 알려져 있다[6]. 생활수준이 향상되고 개선 됨에 따라 평균수명이 높아져 고령화 인구가 증가하고, 노화 와 관계된 질환이 많이 증가하고 있다. 그 중에서도 뇌와 관련 된 질환의 유병률이 높아지고 있다. 이러한 뇌질환을 일으키 는 다양한 메커니즘 중 활성산소종에 의한 산화적 스트레스가 중요한 요인의 하나이다. Glutamate는 중추신경계의 대표적 인 훙분성 신경전달 물질로 신경전달, 행동이나 기억력 등에 중요한 역할을 한다. 하지만 과다하게 분비된 glutamate는 수 용체들을 과도하게 자극하여 산화적 스트레스를 유발한다[3]. 그리고 호기성 호흡을 하는 생물체 특히 포유류는 산소 분자
$\left(\mathrm{O}_{2}\right)$ 를 이용하여 산화환원 효소계나 환원에 대한 면역세포의 반응, 외부의 방사선이나 화합물 등에 의해 활성산소종(ROS) 을 생성한다. 체내 ROS가 많이 생성되면 산화계와 항산화계 의 불균형으로 인해 산화적 스트레스가 일어나게 된다[4]. 이 러한 산화적 스트레스는 신경세포를 손상시키거나 죽게 만들 고[1], 중추신경계의 퇴행성 뇌질환을 유발시키는 주된 원인중 의 하나로 알려져 있다[17]. 항산화시스템과 관련된 Heme oxygenase $(\mathrm{HO})$ 는 세포의 중요한 구성 요소이며 $\mathrm{HO}$ 유도체 중 하나인 HO-1은 세포내에서 Heme을 분해하여 철, biliverdin, 일산화탄소를 만들며 그 부산물들과 함께 세포손상 
및 세포사멸 억제, 항염증 및 항산화 작용을 갖는 것으로 알려 지고 있다[11]. HO-1 발현이 세포 보호와 항산화 작용을 통하 여 산화적 스트레스로부터 뇌세포 손상을 억제한다는 연구가 보고 되어 있다[12].

따라서 본 연구에서는 선행연구[16]에서 항균력이 우수한 10 가지 한약재들을 사용하여 이들 한약재를 Lactobacillus spp. 균주로 발효하였다. 발효액 중에서 뇌세포 보호, 활성산소종 소거와 HO-1의 발현을 유도하는 기능을 검색하고, 또한 이들 한약재가 발효를 통하여 항산화 효과가 증가하거나 Pseudomonas aeruginosa이외 다른 세균이나 식물병원균에 대해 항균활성을 보이는지 확인하고자 하였다. 한약재를 $100 \%$ 메탄올로 추출 하여 농축하고 Lactobacillus spp. 균주로 발효한 후 ethyl acetate로 추출하여 추출물을 제조하여 사용하였다. 10종의 한약 재 가운데 붉나무의 ethyl acetate 추출물에서 뇌세포 보호활 성이 관찰되었다. 붉나무를 발효 후 ethyl acetate 추출물을 대상으로 HT22 세포의 생존율을 측정한 결과 Lactobacillus brevis KCTC 3498로 발효한 ethyl acetate 추출물에서 붉나무 의 methanol 추출물 보다 높은 뇌세포 보호활성이 있는 것으 로 나타났다. 활성산소종 소거능 측정에서도 Lactobacillus brevis KCTC 3498로 발효한 ethyl acetate 추출물의 소거능이 붉 나무의 methanol 추출물 보다 높게 측정이 되었다. HO-1 단백 질 발현을 확인한 결과 역시 Lactobacillus brevis KCTC 3498 로 발효한 ethyl acetate 추출물의 HO-1 발현정도가 높았다. 이러 한 농도의존적인 뇌세포 보호활성과 활성산소종 소거능이 HO-1 단백질 발현간의 직접적인 관계를 알아보기 위하여 HO-1 발현 억제제인 SnPP를 이용한 세포 생존율 실험 및 활 성산소종 소거능을 측정한 결과 뇌세포 보호 효과가 억제되며 활성산소종 소거능도 감소하는 것을 확인하였다. HO-1 단백 질 발현에 관여하는 메커니즘 가운데 $\mathrm{Nrf2}$ 의 핵 내로의 전사 를 확인 한 결과 시간이 지남에 따라 세포질의 Nrf2는 감소하 는 반면, 핵 내부의 Nrf2는 증가하는 양상을 보였다. 이는 Nrf2 의 핵 내로의 전사가 이루어졌음을 확인할 수 있었다. 또한 붉나무 메탄올 추출물과 발효한 붉나무 ethyl acetate 추출물 의 차이를 알아보기 위하여 폴리페놀 함량, ABTS 자유라디칼 소거능, $\mathrm{DPPH}$ 자유라디칼 소거능 측정을 통해 항산화활성을 확인한 결과 발효하기 전보다 항산화활성이 증가 하지는 않았 지만 비슷한 수준까지 항산화활성이 측정되었다. 항균활성을 살펴본 결과에서는 붉나무 메탄올 추출물에서는 나타나지 않 았지만 Bacillus subtilis PCI 219, Escherichia coli KCTC 1682, Shigella flexneri KCTC 2517, Vibrio parahaemolyticus KCTC 7471, Pseudomonas aeruginosa KCTC 2004로 발효한 붉나무 ethyl acetate 추출물에서는 항균활성을 나타내었다. 이와 같 은 결과로 발효한 붉나무의 ethyl acetate 추출물은 발효하기 전보다 항균활성이 좋아지는 것을 확인할 수 있었으며, 식물 에 시드름병을 유발시키는 Fusarium oxysporum $f$ sp. Lycopersici (Saccardo) Snyder \& Hansen KACC 40037에 항균
활성을 보이는 추출물도 관찰할 수 있었다.

본 연구는 발효 한약의 다양한 발효 전후 변화를 알아보고 자 10 가지 한약을 선정하여 발효 하고, 스크리닝을 통해 효과 가 있었던 붉나무의 메탄올 추출물과 발효한 붉나무 ethyl acetate 추출물의 생리 활성 변화 비교를 하였다. 그 결과 발 효한 붉나무 ethyl acetate 추출물은 Nrf2 기전을 통한 HO-1 단백질 발현을 현저히 증가 시켰고 뇌세포 보호효과가 우수 하게 나타났으며, 항균활성이 뚜렷하게 증가 함을 확인할 수 있었다. 따라서, 발효한 붉나무 추출물은 뇌 세포보호 및 미 생물에 의한 손상 치료에 효과가 있을 것으로 사료된다. 추후 연구를 통해 발효 전과 후의 붉나무 추출물 구성성분의 변화 및 활성 변화에 따른 기전 연구가 추가적으로 필요할 것으로 판단된다.

\section{감사의 글}

이 연구는 계명대학교 신약개발연구소 약학대학 특성화 연 구기금으로 이루어졌습니다.

\section{References}

1. Alibright, T. D., Jessel, T. M., Kandel E. R. and Posner, M. I. 2000. Neural science: a century of progress and the mysteries that remain. Cell 18, 209-216.

2. Balogun, E., Hoque, M., Gong, P., Killeen, E., Green, C., Foresti, R., Alam, J. and Motterlini, R. 2003. Curcumin activates the haem oxygenase-1 gene via regulation of Nrf2 and the antioxidant-responsive element. Biochem J371, 887-895.

3. Choi, D. W. 1988. Glutamate nurotoxicity and diseases of the nervous system. Neuron 1, 623-634.

4. Coyle, J. T. and Puttfarcken, P. 1993. Oxidative stress, glutamate and neurodegenerative disorders. Science 262, 689-695.

5. Jeong, H. G. 2001. Selection criteria for probiotics and their industrial applications. Biotech 14, 39-48.

6. Jung, Y. J., Han, D. O., Choi, B. H., Park, C., Lee, H. J., Kim, S. H. and Hahm, D. H. 2007. Effect of fermented herbal extracts, HP-1 on enzyme activity gene expressions related to alcohol metabolism in ethanol-loaded rats. Korean $J$ Oriental Physiology Pathology 21, 387-391.

7. Kim, D. H., Han, S. B., Park, J. S. and Han, M. J. 1994. Fermentation of antler and its biological activity. Korean $J$ Pharmacogn 25, 233-237.

8. Kim, N. J., Jin, Y. H. and Hong, N. D. 1995. Studies on the processing of crude drugs (IV): Physico-chemical transformation of glycyrrhizin in glycyrrhizae radix by processing. Korean J Phamacogn 26, 31-39.

9. Kim, S. Y. 2008. A Study of Korea medicine quality, authentication system. M.D. diss., University of Daegu Haany, Daegu, Korea.

10. Kim, Y. M. 2009. A Study on the trend of researches in fermented herb medicines. M.D. diss., Department of oriental 
medicine, University of Kyungwon, Korea.

11. Lee, H. J., Kang, G. J., Yoon, W. J., Kang, H. K., Kim, Y. S., Kim, S. M. and Yoo, E. S. 2006. Anti-inflammatory effect of unripe fruit of Citrus grandis Osbeck in RAW264.7 and hacat cells. Korean J Pharmacogn 37, 74-810.

12. Lee, M. S., Lee, J., Kwon D. Y. and Kim, M. S. 2006. Ondamtanggamibang protects neurons from oxidative stress with induction of heme oxygenase-1. J Ethnopharmacol 108, 294-298.

13. Park, E. K., Sung, J. H., Trinh, H. T., Bae, E. A., Yun, H. K., Hong, S. S. and Kim, D. H. 2008. Lactic acid bacteria fermentation increases the antiallergic effects of Ixeris dentate. J Microbiol Biotechnol 18, 308-313.

14. Re, R., Pellegrini, N., Proteggente, A., Pannala, A., Yang, M. and Rice-Evans, C. 1999. Antioxidant activity applying an improved ABTS radical cation decolorization assay. Free Radic Biol Med 26, 1231-1237.

15. Rössler, O. G., Bauer, I., Chung H. Y. and Thiel, G. 2004. Glutamate-induced cell death of immortalized murine hippocampal neurons: neuroprotective activity of heme oxygenase-1, heat shock protein 70, and sodium selenite. Neurosci Lett 362, 253-257.

16. Ryu, J. Y., Park Y. J. and Kim, H. S. 2011. Antibacterial activity of fermented Korean medicine against multi-drug resistant Pseudomonas aeruginosa. Korean J Biotech Bioeng 26, 543-551.

17. Satoh, T., Okamoto, S., Cui, J., Watanabe, Y., Furuta, K., Furuta, M., Tohyama, K. and Lipton, S. A. 2006. Activation of the Keap1/Nrf2 pathway for neuroprotection by electrophilic phase II inducers. Proc Natl Acad Sci USA 103, 768-773.

18. Shon, M. Y. 2007. Antioxidant and anticancer activities of Poria cocos and Machilus thunbergii fermented with mycelial mushrooms. Food Ind Nutr 12, 51-57.

19. Shon, M. Y., Nam, S. H. and Lee, S. W. 2007. Antioxidant, anticancer activities and nitric oxide production of Euphoria longana fermented with lactic acid bacteria a Bacillus subtilis. Korean J Food Preserv 14, 531-537.

20. Yoshizawa, S., Horiuchi, T., Fujiki, H., Yoshida, T., Okuda T. and Sugimura. T. 1987. Antitumor promoting activity of (-)-epigallocatechin gallate, the main constituent of tannin in green tea. Phytother Res 1, 44-47.

21. Yu, M. H., Im, H. G., Lee, H. J., Ji Y. J. and Lee, I. S. 2006. Components and their antioxidative of Methanol extracts from sarcocarp and seed of Zizyphus jujube var. inermis Rehder. Korean J Food Sci Technol 38, 128-134.

초록 : Lactobacillus spp. 이용 발효 붉나무의 기능성물질 검색에 대한 연구

이동성 ${ }^{1} \cdot$ 강민수 ${ }^{2} \cdot$ 김윤철 ${ }^{1,3} \cdot$ 임남경 ${ }^{4} \cdot$ 김현수 $^{1}{ }^{*} \cdot$ 정길생 ${ }^{*}$ *

( ${ }^{1}$ 원광대학교 체액조절연구센터, ${ }^{2}$ 계명대학교 자연과학대학 미생물학과, ${ }^{3}$ 원광대학교 약학대학 천연물 신약 표준화 소재은행, ${ }^{4}$ 계명 대학교 신약개발연구소, ${ }^{5}$ 계명대학교 약학대학)

본 연구에서는 한약재를 Lactobacillus속 균주로 발효시켜 기능성물질을 확인하고자 하였다. 선행연구를 통해 선별한 발효에 사용한 10 가지 한약은 $100 \%$ methanol로 추출하여 Lactobacillus속 균주와 MRS배지를 첨가하여 사 용하였고 발효 후 ethyl acetate로 추출하여 사용하였다. 10가지 중 붉나무를 Lb. brevis KCTC 3498로 발효하고 ethyl acetate로 추출한 추출물에서 마우스 해마 유래 세포주인 HT22 세포에서 glutamate로 유발된 산화적 손상 으로부터 세포 보호효과가 우수했으며, 이는 heme oxygenase-1 단백질 발현에 의한 것 임을 밝혔다. 또한, 뇌세 포 보호에 heme oxygenase-1 발현의 주요 기전인 Nrf2 핵 내의 전사와 직접적인 연관이 있음을 확인하였다. 붉나 무의 발효 전과 후의 항균, 항산화 효과 비교 실험에서는 붉나무를 Lb. plantarum subsp. plantarum KCTC 3108, Lb. fermentum KCTC 3112, Lb. brevis KCTC 3498 균주로 각각 발효한 한약재는 발효 전보다 항산화 활성이 높아 지거나 비슷한 수준으로 나타났다. Lb. plantarum subsp. plantarum KCTC 3108, Lb. casei KCTC 3109로 발효한 붉나무 발효액과 ethyl acetate 여액층은 Bacillus subtilis PCI 219, Escherichia coli KCTC 1682, Shigella flexneri KCTC 2517, Vibrio parahaemolyticus KCTC 7471, Pseudomonas aeruginosa KCTC 2004에 모두 항균활성을 보였다. 붉나무를 Lb. brevis KCTC 3498로 발효하여 ethyl acetate로 추출한 추출물은 B. subtilis PCI 219, E. coli KCTC 1682 , S. flexneri KCTC 2517, V. parahaemolyticus KCTC 7471 균주에서 발효한 추출물이 단순 붉나무 추출물보다 높은 항균활성을 보였다. 